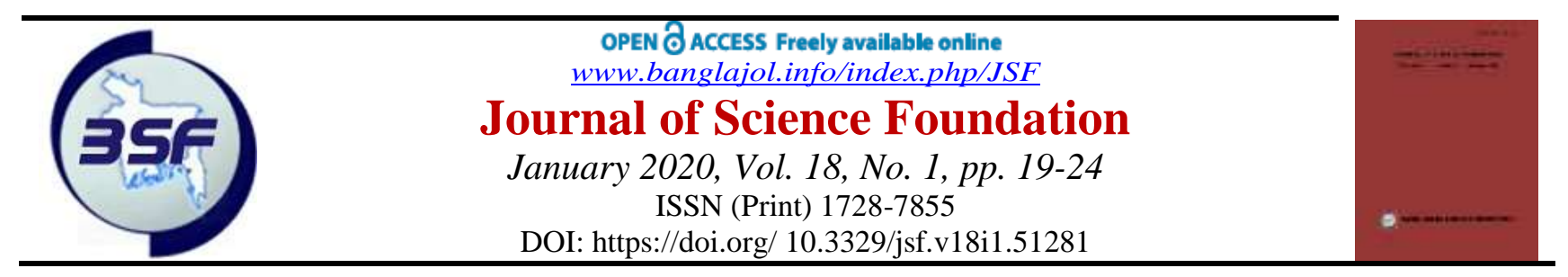

Original Article

\title{
Comparison of Serum Lipid Profiles of Women with or Without Hormonal Contraceptives Users at a Tertiary Care Hospital in Dhaka City
}

\author{
Kashifa Khatun ${ }^{1}$, Naznin Rashid Shewly ${ }^{2}$, Shimul Akter ${ }^{3}$, Sultana Afroj ${ }^{4}$, Nilofar Yasmin ${ }^{5}$, Fazle \\ Noor-e Tawhida ${ }^{6}$, Shamsun Nahar ${ }^{7}$
}

\begin{abstract}
Background: Both oral and injectable hormonal contraceptives are the most popular type of birth control measures used in Bangladesh. Objective: The purpose for the present study was to see the effects of hormonal contraceptives on serum lipid profiles. Methodology: This was case-control study which was carried out in the Department of Obstetrics \& Gynaecology at Bangabandhu Sheikh Mujib Medical University (BSMMU), Dhaka, Bangladesh from July 2004 to December 2005 for eighteen (18) months. Women of reproductive age group who had given the history of taking low-dose OCP containing $30 \mathrm{meg}$ EE plus 150 meg LNG were included as case group and women who were presented without the history of hormonal contraceptives use were included as control group. Blood was collected from each woman in fasting state and serum was sent for estimation of serum lipids profiles like serum triglycerides, total cholesterol, LDL and HDL. Result: The study included 40 women (control) who were not using OCP and 40 women (case) who were using OCP for more than one year. Comparison of age between control $(31.75 \pm 4.85$ years) and case $(30.43 \pm 5.44$ years) groups showed no significant difference $(p>0.05)$. No significant difference with raised cholesterol levels $(207.50 \pm 3.54$ and $254.71 \pm 45.54 \mathrm{mg} / \mathrm{dl})$ was reported. Comparison of normal $(136.16 \pm 39.46$ and $154.05 \pm 35.33 \mathrm{mg} / \mathrm{dl})$ and raised $(229.00 \pm 24.52$ and $246.32 \pm 35.98 \mathrm{mg} / \mathrm{dl}$ ) triglyceride levels between control and case groups did not statistically significant. Comparison of normal and raised HDL levels did not show statistically any significant difference in control $(32.07 \pm 3.02 \mathrm{mg} / \mathrm{dL})$ and case $(32.48 \pm 1.76 \mathrm{mg} / \mathrm{dL})$ groups. Mean $( \pm \mathrm{SD})$ of normal and raised levels of LDL was significantly high in case group. Normal LDL level was $82.71 \pm 26.82$ and $111.05 \pm 15.40 \mathrm{mg} / \mathrm{dl}$ and raised LDL level was $138.55 \pm 3.03$ and $188.82 \pm 40.37 \mathrm{mg} / \mathrm{dL}$. Conclusion: In conclusion use of low-dose OCP containing 30 meg EE plus 150 meg LNG significantly increases serum cholesterol, serum triglyceride and LDL-cholesterol levels but not HDL-cholesterol. [Journal of Science Foundation, January $2020 ; 18(1): 19-24]$
\end{abstract}

Keywords: Contraceptives; cholesterol; LDL; HDL; triglycerides; OCP

[Reviewed: 3 November 2019; Accepted on: 1 December 2019; Published on: 1 January 2020]

\footnotetext{
${ }^{1}$ Associate Professor, Department of Gynaecology \& Obstetrics, Dhaka Medical College, Dhaka, Bangladesh

${ }^{2}$ Associate Professor, Department of Gynaecology \& Obstetrics, Shaheed Suhrawardy Medical College, Dhaka, Bangladesh

${ }^{3}$ Assistant Professor, Department of Gynaecology and Obstetrics, Monowara Sikder Medical College, Shariatpur, Bangladesh

${ }^{4}$ Associate Professor, Department of Obstetrics \& Gynaecology, Dhaka Medical College, Dhaka, Bangladesh

${ }^{5}$ Associate Professor, Department of Obstetrics \& Gynaecology, Shaheed Suhrawardy Medical College, Dhaka, Bangladesh

${ }^{6}$ Junior Consultant (Obstetrics \& Gynaecology), Dhaka Medical College \& Hospital, Dhaka, Bangladesh

${ }^{7}$ Assistant Professor, Department of Gynaecology and Obstetrics, Abdul Malek Ukil Medical College, Noakhali, Bangladesh
}

Correspondence: Dr. Kashifa Khatun, Associate Professor, Department of Gynaecology \& Obstetrics, Dhaka Medical College, Dhaka, Bangladesh; Email: kashefa.khatun022@ gmail.com; Cell no.: +8801819127441

Copyright: (02020. Khatun et al. Published by Journal of Science Foundation. This article is distributed under the terms of the Creative Commons Attribution 4.0 International CC BY-NC License (https://creativecommons.org/licenses/by-nc/4.0/). This license permits unrestricted use, distribution and reproduction in any medium, provided the original work is properly cited, you give appropriate credit to the original author( $s$ ) and is not used for commercial purposes 


\section{Introduction}

During the past three decades, oral contraceptives pills (OCP) have changed substantially (Endrikat et al., 2002). These changes have occurred in the dose and type of both the estrogen and progestogen components. A number of side effects are encountered by the users like nausea, vomiting, dizziness, metabolic disorders, hypertension, diabetic, thromboembolism (Barkfeldt et al., 2001). Estrogen component of the oral contraceptive pills (OCP) was initially implicated but later it has been shown that gestagen component too played a vital role in enhancing cardiovascular side effect (Lubianca et al., 2003). Although ethinyl estradiol generally had a favourable impact on lipid patterns, the progestins in the early products have diminished these benefits. The newer and less androgenic progestins norgestimate and desogestrel have either a neutral or a beneficial effect on lipid profiles (Sitruk-Ware 2006).

Since millions of women currently use OCR, it is important to delineate the changes in serum lipid levels with its use (Mia et al., 2005). Hyperlipidemia has emerged as one of the most important preventable and modifiable risk factors for coronary heart diseases. Clinical signs of this condition are an increase in the fasting serum cholesterol levels or the fasting serum triglyceride levels or both (Okeke et al., 2012). Lipid levels may be affected by diet, exercise, smoking, certain medications like beta blockers, thiazide diuretics, glucocorticoids and use of OCPs (Nessa et al., 2007).

The major plasma lipids are cholesterol, triglycerides, and phospholipids. Lipoproteins are macromolecular complexes that play an important role in the transport and metabolism of lipids. Total cholesterol (TC) is a sum of high-density lipoprotein (HDL) cholesterol, low-density lipoprotein (LDL) cholesterol and 20.0\% of the triglyceride value (Berenson et al., 2008). TC level is an excellent predictor of coronary heart diseases. The variable effects of OCPs on plasma lipids and blood glucose level depend on their relative estrogen and progestin content as well as their specific progestin component ${ }^{1}$. Although, varying degrees of elevation of plasma lipids have been reported with the use of the older combination OCPs, the newly developed monophasic and triphasic ethinyl estradiol/norgestimate preparations have consistently shown a favourable impact on these metabolic parameters, especially the HDL level and LDL7HDL ratio (Frempong et al., 2008).

The increase in cholesterol, triglycerides and LDL increases the risk of coronary heart disease (Pantoja et al., 2009). So this study has been planned to be conducted in BSMMU to ascertain the changes in lipids of Bangladeshi women after use of low dose OCR contain 30 micrograms (meg) of ethinyl estradiol (EE) and 150 micrograms of levonorgestrel (LNG) for more than 1 year and to compare the serum cholesterol, HDL, LDL and triglycerides with healthy women who did not use oral pills or hormonal contraceptives.

\section{Methodology}

This was a prospective cross-sectional study. This study was carried out in the Department of Obstetrics \& Gynaecology in collaboration with the Biochemistry Department at Bangabandhu Sheikh Mujib Medical University (BSMMU), Dhaka, Bangladesh. The study period was from July 2004 to December 31, 2005for eighteen (18) months. Study subjects were collected from the family planning department of BSMMU and DMCH (Dhaka Medical College Hospital) during the study period. This study included women who were not using any oral or hormonal contraceptives, and 40 women who were using low dose OCR containing 30 meg EE plus 150 LNG for more than one year. Purposive sampling technique was applied for this study. The researcher herself interviewed the respondents according to their convenience. Women of reproductive age (20-40 years), history of no oral or hormonal contraceptive use (control) or history of taking low-dose OCP containing 30 meg EE plus 150 meg LNG for more than one year (case), women presented with normotensive, non-diabetic, nonsmoker, nonalcoholic were included as study population. Women with systemic disease, like liver disease, kidney disease, which secondarily affect lipid metabolism, history of using beta-blockers, thiazide diuretics, glucocorticoids and women using other than above oral or hormonal contraceptives were excluded from this study.

Before starting the research work, permission was taken from the hospital authorities. After selection of study subjects, detailed history was taken and a careful physical examination was performed. Subjects were requested to fast overnight (10-12 hours) and to report at around 9 a.m. in the Department of Biochemistry, BSMMU, for laboratory tests. Five milliletre blood was collected from each subject with disposable syringe by antecubital venipuncture, taking full aseptic precautions. After removal of needle from the syringe, blood 
was transferred into a plain test tube for estimation of serum lipids. The plain test tubes were kept in standing position. After dot formation and retraction of clot, the serum was separated as quickly as possible from the sample by centrifugation for 10 minutes at $3000 \mathrm{rpm}$. The clear serum obtained after centrifugation was preserved in a screw-capped test tube and stored at $-35^{\circ}$ to $-36^{\circ} \mathrm{C}$ for subsequent use. To avoid diurnal variation, samples were collected always between 8-9 a.m. The followings were estimated as outcome variables from the preserved serum.

All relevant information was recorded in a predesigned data collection sheet. Collected data were compiled and appropriate statistical analyses (Unpaired t test and Chi-square test) were done using computer based software, Statistical Package for Social Science (SPSS, Version 20.0). P value $<0.05$ was taken as minimum level of significance.

\section{Results}

This present study was carried out in the Department of Obstetrics and Gynaecology at Bangabandhu Sheikh Mujib Medical University (BSMMU), Dhaka to evaluate the lipidaemic status of Bangladeshi women using low-dose oral contraceptive pills (OCP). The study included 40 women (control) who were not using OCP and 40 women (case) who were using OCP for more than one year.

Comparison of age between control and case groups showed no significant difference (Mean \pm SD $31.75 \pm 4.85$ vs $30.43 \pm 5.44$ years, respectively). Mean $( \pm \mathrm{SD})$ weight of control and case groups were $52.78 \pm 4.02$ and $53.23 \pm 5.89 \mathrm{~kg}$, respectively, which also showed statistically no significant difference. Mean $( \pm \mathrm{SD})$ parity was $2.48 \pm 0.91$ in control group and $2.70 \pm 0.94$ in case group, and there was no significant difference between groups (Table 1).

Table 1: Comparison of Age, Weight and Parity of the Study Subject

\begin{tabular}{|c|c|c|c|}
\hline Parameters & Case $(n=40)$ & Control $(n=40)$ & $\mathrm{p}$ value \\
\hline $\begin{array}{l}\text { Age } \quad \text { (years) } \\
\text { Mean } \pm \text { SD Range }\end{array}$ & $\begin{array}{l}31.75 \pm 4.85 \\
22-40\end{array}$ & $\begin{array}{l}30.43 \pm 5.44 \\
20-40\end{array}$ & $>0.10^{\mathrm{ns}}$ \\
\hline $\begin{array}{l}\text { Weight }(\mathrm{kg}) \\
\text { Mean } \pm \text { SD Range }\end{array}$ & $\begin{array}{l}52.78 \pm 4.02 \\
46-66\end{array}$ & $\begin{array}{l}53.23 \pm 5.89 \\
39-70\end{array}$ & $>0.50^{\mathrm{ns}}$ \\
\hline $\begin{array}{l}\text { Parity } \\
\text { Mean } \pm \text { SD Range }\end{array}$ & $\begin{array}{l}2.48 \pm 0.91 \\
1-4\end{array}$ & $\begin{array}{l}2.70 \pm 0.94 \\
1-5\end{array}$ & $>0.10^{\mathrm{ns}}$ \\
\hline
\end{tabular}

Unpaired student's ' $\mathrm{t}$ ' test; $\mathrm{ns}=$ Not significant

Normal cholesterol level showed significant difference between control and case groups $(153.82 \pm 30.80$ and $185.20 \pm 1.95 \mathrm{mg} / \mathrm{dl})$ but showed no significant difference with raised cholesterol levels $(207.50 \pm 3.54$ and $254.71 \pm 45.54 \mathrm{mg} / \mathrm{dl})$. Comparison of normal $(136.16 \pm 39.46$ and $154.05 \pm 35.33 \mathrm{mg} / \mathrm{dl})$ and raised $(229.00 \pm 24.52$ and $246.32 \pm 35.98 \mathrm{mg} / \mathrm{dl})$ triglyceride levels between control and case groups did not statistically any significant difference.

Likewise, Comparison of normal and raised HDL levels between control and case groups did not show statistically any significant difference. Mean $( \pm \mathrm{SD})$ normal HDL level of control and case groups were $32.07 \pm 3.02$ and $32.48 \pm 1.76 \mathrm{mg} / \mathrm{dl}$, and raised $\mathrm{HDL}$ level were $43.63 \pm 7.23$ and $45.94 \pm 5.86 \mathrm{mg} / \mathrm{dl}$, respectively. Mean $( \pm \mathrm{SD})$ normal and raised levels of LDL was significantly high in case group. Normal LDL level was $82.71 \pm 26.82$ and $111.05 \pm 15.40 \mathrm{mg} / \mathrm{dl}$ and raised LDL level was $138.55 \pm 3.03$ and $188.82 \pm 40.37 \mathrm{mg} / \mathrm{dl}$ (Table 2).

Table 2: Comparison of Mean $( \pm \mathrm{SD})$ Values of Lipid Levels between Two Groups

\begin{tabular}{|l|l|l|l|}
\hline Lipid Profiles & Control Group & Case Group & p value \\
\hline Cholesterol (mg/dL) & \multicolumn{3}{|l|}{} \\
\hline Normal & $153.82 \pm 30.80$ & $185.20 \pm 11.95$ & $<0.05^{*}$ \\
\hline Raised & $207.50 \pm 3.54$ & $254.71 \pm 45.51$ & $>0.10^{\text {ns }}$ \\
\hline
\end{tabular}




\begin{tabular}{|l|l|l|l|}
\hline Triglycerides (mg/dL) \\
\hline Normal & $136.16 \pm 39.46$ & $154.05 \pm 35.98$ & $>0.05 \mathrm{~ns}$ \\
\hline Raised & $229.00 \pm 24.52$ & $246.32 \pm 35.98$ & $>0.10^{\text {ns }}$ \\
\hline HDL (mg/dL) & $32.07 \pm 3.02$ & $32.48 \pm 1.76$ & $>0.05 \mathrm{~ns}$ \\
\hline Normal & $43.63 \pm 7.23$ & $45.94 \pm 5.86$ & $>0.10^{\text {ns }}$ \\
\hline Raised ( $\leq 35)$ & $82.71 \pm 26.82$ & $111.05 \pm 15.40$ & $<0.01^{* *}$ \\
\hline LDL (mg/dl) & $138.55 \pm 3.03$ & $188.82 \pm 40.37$ & $<0.05^{\text {ns }}$ \\
\hline Normal & & & \\
\hline Raised $(\leq 35)$ &
\end{tabular}

Unpaired student's ' $\mathrm{t}$ ' test; $\mathrm{ns}=$ Not significant; $* / * *$ Significant

Total cholesterol was raised in 35 cases and 2 cases in case and control group respectively ( $\mathrm{p}=0.00001$ ). Serum triglycerides was raised in 19 cases and 3 cases in case and control group respectively ( $\mathrm{p}=0.000062$ ). HDL was raised in 31 cases and 26 cases in case and control group respectively ( $\mathrm{p}=0.592)$. LDL was raised in 27 cases and 4 cases in case and control group respectively ( $\mathrm{p}=0.00001)$ (Table 3 ).

Table 3: Comparison of Lipid Levels between Study Groups According To Status of Lipids

\begin{tabular}{|c|c|c|c|}
\hline Parameters & $\begin{array}{l}\text { Case } \\
\text { Group }\end{array}$ & $\begin{array}{l}\text { Control } \\
\text { Group }\end{array}$ & p value \\
\hline \multicolumn{4}{|c|}{ Total Cholesterol (mg/dL) } \\
\hline Normal $(\leq 200)$ & 5 & 38 & \multirow{3}{*}{0.00001} \\
\hline Raised (>200) & 35 & 2 & \\
\hline Total & 40 & 40 & \\
\hline \multicolumn{4}{|c|}{ Triglycerides (mg/dL) } \\
\hline Normal $(\leq 200)$ & 21 & 37 & \multirow{3}{*}{0.000062} \\
\hline Raised (>200) & 19 & 3 & \\
\hline Total & 40 & 40 & \\
\hline \multicolumn{4}{|l|}{ HDL (mg/dL) } \\
\hline Normal $(\leq 35)$ & 13 & 14 & \multirow{3}{*}{0.592} \\
\hline Raised $(\leq 35)$ & 31 & 26 & \\
\hline Total & 40 & 40 & \\
\hline \multicolumn{4}{|l|}{ LDL (mg/dL) } \\
\hline Normal $(<130)$ & 13 & 36 & \multirow{3}{*}{0.00001} \\
\hline Raised $(\leq 35)$ & 27 & 4 & \\
\hline Total & 40 & 40 & \\
\hline
\end{tabular}

*Chi-square test was performed to see the level of significance

\section{Discussion}

Oral Contraceptive Pills are combined formulations of a progestin and a synthetic estrogen (Oyelola 1993). These are widely used and generally safe and effective for many women. But a number of side effects may be encountered by the users of which changes in serum lipid profile is of importance because of the involvement of lipoproteins in endothelial damage and arterial occlusion (Oyelola 1993).

This study was conducted on Bangladeshi women who used OCP for more than 1 year. The main aim of this study was to compare the changes in serum cholesterol, HDL, LDL and triglyceride (levels between healthy 
women who not use oral pills or hormonal contraceptives and women using lost dose pill containing (Song et al., 1992).

The study included 40 women (control) who were not using OCP and 40 women (case) who were using OCP for more than one year. Comparison of age between control and case groups showed no significant difference (Mean \pm SD $31.75 \pm 4.85$ vs $30.43 \pm 5.44$ years, respectively). Mean $( \pm \mathrm{SD})$ weight of control and case groups were $52.78 \pm 4.02$ and $53.23 \pm 5.89 \mathrm{~kg}$, respectively, which also showed statistically no significant difference. Mean $( \pm \mathrm{SD})$ parity was $2.48 \pm 0.91$ in control group and $2.70 \pm 0.94$ in case group, and there was no significant difference between groups.

Normal cholesterol level showed significant difference between control and case groups $(153.82 \pm 30.80$ and $185.20 \pm 1.95 \mathrm{mg} / \mathrm{dl})$ but showed no significant difference with raised cholesterol levels $(207.50 \pm 3.54$ and $254.71 \pm 45.54 \mathrm{mg} / \mathrm{dl})$. Total cholesterol was raised in 35 cases and 2 cases in case and control group respectively $(\mathrm{p}=0.00001)$. Comparison of normal $(136.16 \pm 39.46$ and $154.05 \pm 35.33 \mathrm{mg} / \mathrm{dl})$ and raised $(229.00 \pm 24.52$ and $246.32 \pm 35.98 \mathrm{mg} / \mathrm{dl})$ triglyceride levels between control and case groups did not statistically any significant difference. Again, serum triglycerides was raised in 19 cases and 3 cases in case and control group respectively $(\mathrm{p}=0.000062)$. Serum triglyceride level was significantly higher $(\mathrm{P}<0.001)$ in cases in comparison to control. In another work conducted by Song et al (1992) it is found that triglycerides are increased by the desogestrel OCPs but not by levonorgestrel OCPs.

Likewise, Comparison of normal and raised HDL levels between control and case groups did not show statistically any significant difference. Mean $( \pm \mathrm{SD})$ normal HDL level of control and case groups were $32.07 \pm 3.02$ and $32.48 \pm 1.76 \mathrm{mg} / \mathrm{dl}$, and raised HDL level were $43.63 \pm 7.23$ and $45.94 \pm 5.86 \mathrm{mg} / \mathrm{dl}$, respectively. Again, HDL was raised in 31 cases and 26 cases in case and control group respectively $(\mathrm{p}=0.592)$. Van Rooijen et al (2002) has compared the effect of levonorgestrel or desogestrel on plasma lipoproteins (with same amount of EE) and has found that HDL concentration increases significantly with treatment with EE/DSG when compared with baseline and treatment with EE/LNG. There was statistically significant increase observed in cases compared to control of HDL level. In a study conducted by Song et al (1992) it was found that HDL-c decreased significantly with Microgynen (containing 30 meg of EE +150 meg of LNG).

Mean $( \pm \mathrm{SD})$ normal and raised levels of LDL were significantly high in case group. Normal LDL level was $82.71 \pm 26.82$ and $111.05 \pm 15.40 \mathrm{mg} / \mathrm{dL}$ and raised LDL level was $138.55 \pm 3.03$ and $188.82 \pm 40.37 \mathrm{mg} / \mathrm{dL}$. LDL was raised in 27 cases and 4 cases in case and control group respectively ( $\mathrm{p}=0.00001)$. Serum LDL level significantly increased $(\mathrm{p}<0.001)$ in cases as compared to control. This observation is consistent with Song et al (1992). This study also shows the exact rise in serum lipid levels among the users of OCP compared to controls who did not use any forms of hormonal contraceptives. Here it is also quite evident that the serum cholesterol was raised $>200 \mathrm{mg} / \mathrm{dL}$ in only $2(5 \%)$ of control group, whereas, high level of serum cholesterol was observed in $35(87.5 \%)$ out of 40 study subjects $(\mathrm{P}<0.001)$.

\section{Conclusions}

In conclusion use of low dose OCP containing $30 \mathrm{meg}$ EE and 150 LNG significantly increases serum cholesterol, serum triglyceride and LDL cholesterol levels but not HDL cholesterol. However, duration of OCP use for less than 5 years and more than 5 years did not show any significant variation on the above lipids. A further study with estimation of lipid profile of the cases before the start of OCP may be done.

\section{References}

Barkfeldt J, Virkkunen A, Dieben T. The effects of two progestogen-only pills containing either desogestrel (75 microg/day) or levonorgestrel (30 microg/day) on lipid metabolism. Contraception 2001;64(5):295-299

Berenson AB, Rahman M, Wilkinson G. Effect of injectable and oral contraceptives on serum lipids. Obstet Gynecol. 2009;114(4):786-794

Endrikat J, Klipping C, Cronin M, et al. An open label, comparative study of the effects of a dose-reduced oral contraceptive containing 20 microg ethinyl estradiol and 100 microg levonorgestrel on hemostatic, lipids, and carbohydrate metabolism variables. Contraception 2002; 65(3):215-221

Frempong BA, Ricks M, Sen S, Sumner AE. Effect of low-dose oral contraceptives on metabolic risk factors in African-American women. J Clin Endocrinol Metab. 2008;93(6):2097-2103

Lubianca JN, Faccin CS, Fuchs FD. Oral contraceptives: a risk factor for uncontrolled pressure among hypertensive women. Contraception. 2003;67(1):19-24

Mia AR, Siddiqui NI, Islam MN, Khan MR, Shampa SS, Rukunuzzaman M. Effects of prolonged use of injectable hormonal 
contraceptive on serum lipid profile. Mymensingh Med J. 2005;14(1):19-21

Nessa A, Latif SA, Uddin MM, Hussain MA. Serum HDL-cholesterol in women using low dose oral contraceptives. Mymensingh Med J. 2007;16(Suppl 2):S3-S6

Okeke CU, Braide SA, Okolonkwo BN, et al. Comparative effects of injectable and oral hormonal contraceptives on lipid profile. Eur J Cardio Med. 2012;2(1):20-23

Oyelola OO. Fasting plasma lipid, lipoproteins and apolipoproteins in Nigerian women using combined oral and progestin-only injectable contraceptives. Contraception 1993; 47(5): 445-454

Pantoja M, Medeiros T, Baccarin MC, Morais S, Fernandes AM. Variation of weight among users of the contraceptive with depotmedroxyprogesterone acetate according to body mass index in a six-year follow-up. Rev Bras Ginecol Obstet. 2009;31(8):380384

Sitruk-Ware R. New progestagens for contraceptive use. Hum Reprod Update. 2006;12(2):169-178.

Song S, Chen JK, Yang PJ, He ML, Li LM, Fan BC, et al. A cross-over study of three oral contraceptives containing ethinyloestradiol and either desogestrel or levonorgestrel. Contraception 1992; 45:523-32

Van Rooijen M, Von Schoultz B, Silveira A, Hamsten A, Bremme K. Different effects of oral contraceptives containing levonorgestrel or desogestrel on plasma lipoprotein and coagulation factor VII. Am J Obstet Gynecol 2002; 186:44-8 